\title{
II Śląskie Forum Karnoprocesowe pt. „Konstytucyjne podstawy procesu karnego”. Katowice, 12 października 2017 r.
}

W dniu 12 października 2018 r. na Wydziale Prawa i Administracji Uniwersytetu Śląskiego w Katowicach odbyła się ogólnopolska konferencja naukowa pt. „Konstytucyjne podstawy procesu karnego”, która stanowiła drugą już odsłonę corocznego wydarzenia naukowego, jakim jest Śląskie Forum Karnoprocesowe. Konferencja zorganizowana została przez Katedrę Prawa Karnego Procesowego UŚ we współpracy z Kołem Naukowym Prawa Karnego Procesowego „IUSTITIA”, Okręgową Radą Adwokacką w Katowicach oraz Naczelną Radą Adwokacką. Patronat honorowy nad wydarzeniem objął m.in. Sąd Najwyższy, Rzecznik Praw Obywatelskich, Stowarzyszenie Prokuratorów „Lex Super Omnia”, Naczelna Rada Adwokacka oraz Okręgowa Rada Adwokacka w Katowicach.

Otwarcia konferencji w imieniu Władz Wydziału Prawa i Administracji UŚ dokonał Prodziekan dr hab. prof. UŚ Piotr Pinior, który powitał zebranych gości, a następnie podkreślił szczególne znaczenie przyjętego przez organizatorów konferencji tematu, mając na względzie ostatnie niepokojące zmiany wprowadzone na gruncie prawa konstytucyjnego oraz procesu karnego. Następnie głos zabrali Prezes Sądu Apelacyjnego Pani Barbara Suchowska oraz Dziekan Izby Adwokackiej w Katowicach adw. Roman Kusz, którzy także wskazali na szczególną doniosłość poruszanego tematu.

Konferencja podzielona została na dwa panele. Pierwszy z nich zainaugurowany został wystąpieniem dr. hab. Mariusza Jagielskiego, zatytułowanym „Znaczenie i rola norm konstytucyjnych w kontekście procesu karnego". Referat ten, dzięki spojrzeniu na proces karny z per- 
spektywy prawa konstytucyjnego, stanowił doskonałe wprowadzenie do dalszych, szczegółowych rozważań. Jako kolejny głos zabrał dr hab. prof. UŚ Radosław Koper z Katedry Prawa Karnego Procesowego Uniwersytetu Śląskiego. W swym wystąpieniu dotyczącym jawności rozprawy głównej prof. R. Koper poruszył kwestię najnowszych zmian wprowadzonych do Kodeksu postępowania karnego, a dotyczących jawności zewnętrznej rozprawy głównej. Jednym z problemów zasygnalizowanych przez Profesora była zmiana art. 357 k.p.k., w wyniku której sąd zobowiązany jest dopuścić przedstawicieli mediów do udziału w rozprawie. Automatyzm tej decyzji może budzić wątpliwości na gruncie szeroko pojętego prawa do prywatności. W wystąpieniu nie zabrakło również odniesienia do zmiany art. 360 k.p.k., a zwłaszcza unormowania zawartego w dodanym $§ 2$ tego przepisu, przewidującego, że sprzeciw prokuratora uniemożliwia sądowi wyłączenie jawności rozprawy w wypadkach przewidzianych w art. 360 $\$ 1$ k.p.k. W opinii prelegenta powyższe rozwiązanie normatywne prowadzi do wyraźnego zaburzenia podziału ról pomiędzy oskarżycielem publicznym a sądem i czyni prokuratora rzeczywistym dominus litis postępowania jurysdykcyjnego w aspekcie podejmowania decyzji co do jawności rozprawy.

Ostatni referat w ramach pierwszego panelu wygłoszony został przez Zastępcę Rzecznika Praw Obywatelskich Stanisława Trociuka, który przedstawił konstytucyjne aspekty procesu karnego w działalności Rzecznika Praw Obywatelskich. Wystąpienie miało na celu wypunktowanie najnowszych zmian normatywnych, które zwracają uwagę Rzecznika Praw Obywatelskich pod kątem ewentualnego naruszenia praw jednostki. S. Trociuk wskazał w tym względzie m.in. na treść art. 168a k.p.k., umożliwiającego wprowadzanie do procesu karnego tzw. dowodów nielegalnych, uznając, że w unormowaniu tym należy upatrywać naruszenia konstytucyjnej zasady praworządności, zakładającej działanie organów państwa na podstawie i w granicach prawa. Zdaniem Rzecznika rozwiązanie prawne przewidziane $\mathrm{w}$ powołanym przepisie stanowi również ograniczenie prawa do obrony, ponieważ utrudnia oskarżonemu i jego obrońcy racjonalne przewidywanie działań oskarżyciela publicznego. W swoim wystąpieniu S. Trociuk podniósł ponadto wątpliwości nasuwające się na tle art. $137 \$ 2$ Prawa o prokuraturze, który to artykuł przewiduje wyłączenie odpowiedzialności dyscyplinarnej prokuratora za działanie lub zaniechanie podjęte wyłącznie $\mathrm{w}$ interesie społecznym. W ocenie prelegenta przepis ten stanowi sui generis kontratyp odpowiedzialności dyscyplinarnej za oczywiste i rażące naruszenie prawa i uchybienie godności urzędu.

Po przerwie nastąpiło rozpoczęcie kolejnego panelu, zainaugurowanego wystąpieniem adw. dr Dominiki Lapawy, która przedstawiła problematykę pozaustawowego kontratypu działania w ramach uprawnień wyni- 
kających z prawa do obrony w kontekście nowelizacji art. 233 §1a k.k. D. Lapawa zwróciła uwagę na istotną kwestię ewentualnej odpowiedzialności karnej za składanie fałszywych zeznań przez świadka będącego rzeczywistym sprawcą przestępstwa. Odwołując się do obowiązku zeznawania prawdy wyraziła pogląd, że regulacja ta stoi w sprzeczności z zasadą nemo se ipsum accusare tenetur. Wobec powyższego w swoim wystąpieniu prelegentka sformułowała postulat de lege ferenda, aby klauzula niekaralności z art. 233 k.k. adresowana była do świadków będących rzeczywistymi sprawcami przestępstwa. Taka proponowana klauzula mogłaby zostać zawarta w art. 233 §3a k.k. w następującym brzmieniu: „Nie podlega karze sprawca przestępstwa, który w obawie przed odpowiedzialnością karną grożącą jemu samemu za popełniony czyn składa fałszywe zeznania dotyczace tego czynu".

W roli kolejnego prelegenta wystąpił Mariusz Krasoń z Prokuratury Regionalnej w Krakowie. Jego referat dotyczył problematyki „owoców zatrutego drzewa”. W pierwszej części wystąpienia Pan Prokurator zarysował linię orzeczniczą Sądu Najwyższego oraz Trybunału Konstytucyjnego w zakresie dotyczącym możliwości wykorzystania dowodu uzyskanego nielegalnie. Następnie zwrócił uwagę na wprowadzony z dniem 1 lipca 2015 r. przepis art. 168a k.p.k., który w pierwotnym brzmieniu uniemożliwiał przeprowadzenie i wykorzystanie dla celów procesu karnego dowodu uzyskanego za pomocą czynu zabronionego z art. 1 k.k. Regulacja ta ustąpiła miejsca przekształconemu w ramach nowelizacji z dnia 11 marca 2016 r. art. 168a k.p.k. i towarzyszącemu mu art. 168b k.p.k. M. Krasoń wskazał jednocześnie, że w wyniku powyższej zmiany ustawodawca dokonał modyfikacji w przedmiocie organu wyrażającego następczą zgodę na wykorzystanie dowodów uzyskanych w ramach kontroli operacyjnej w zakresie nieobjętym postanowieniem sądu - nastąpiło bowiem przeniesienie tego obowiązku z sądu na prokuratora, co w jego opinii może budzić wątpliwości z perspektywy konstytucyjnie zagwarantowanego prawa do sądu. Prelegent zauważył, że w wyniku omawianej zmiany pierwotna ingerencja $\mathrm{w}$ prawa $\mathrm{i}$ wolności obywatelskie następuje wskutek decyzji sądu, natomiast gdy w toku inwigilacji zajdzie potrzeba jej podmiotowego lub przedmiotowego rozszerzenia, zgodę podejmuje nie sąd, lecz prokurator. M. Krasoń podkreślił również to, że odstąpiono od sformułowanego wprost $\mathrm{w}$ przepisie wymogu, zgodnie z którym zgodą następczą mogą być objęte wyłącznie przestępstwa katalogowe - dotychczas bowiem zgoda tak mogła dotyczyć wyłącznie czynów enumeratywnie wymienionych w zamkniętych katalogach ujętych w przepisach kompetencyjnych. Pan Prokurator wyraził zapatrywanie, że powyższe rozwiązanie może budzić poważne wątpliwości w odniesieniu do orzecznictwa Trybunału Konstytucyjnego czy Europejskiego Trybunału Praw Człowieka. 
Panel drugi zamknęło wystąpienie dr Katarzyny Sychty z Katedry Prawa Karnego Procesowego Uniwersytetu Śląskiego, dotyczące konstytucyjnych i prawnomiędzynarodowych gwarancji kontroli instancyjnej. K. Sychta na wstępie wskazała, że regulacje prawnomiędzynarodowe dotyczące możliwości zaskarżenia rozstrzygnięcia pierwszoinstancyjnego nie mają charakteru absolutnego, bowiem w niektórych wypadkach zezwalają na wyłączenie zasady kontroli instancyjnej. Zdaniem prelegentki nie do zaakceptowania z perspektywy standardów międzynarodowych byłoby pełne wyłączenie kontroli instancyjnej w zakresie winy, jeśli byłaby ona przedmiotem kontradyktoryjnego sporu sądowego. Przyjmując inną perspektywę, K. Sychta podkreśliła, że nie musi pozostawać w kolizji $\mathrm{z}$ uregulowaniami prawa międzynarodowego wyłączenie kontroli instancyjnej $\mathrm{w}$ sprawach zakończonych $\mathrm{w}$ trybach konsensualnych, pod tym jednak warunkiem, że będzie temu towarzyszyła rzetelna ocena treści zawartego porozumienia oraz pełna i dobrowolna zgoda oskarżonego na warunki skazania.

W toku dyskusji, która miała miejsce po zamknięciu drugiego panelu, podniesiono m.in. szczególne znaczenie standardów konstytucyjnych oraz norm prawa międzynarodowego w kontekście wykładni i stosowania przepisów prawa karnego procesowego. Zaakcentowano, że ze względu na liczne i niejednokrotnie wielce dyskusyjne zmiany normatywne na gruncie prawa i procesu karnego, które miały miejsce w ostatnich latach, szczególnego znaczenia nabiera kwestia bezpośredniego stosowania konstytucji, a także norm prawa międzynarodowego w przypadku ich kolizji z prawem wewnętrznym.

Tytułem podsumowania należy wskazać, że II Śląskie Forum Karnoprocesowe stanowiło miejsce ożywionej dyskusji oraz wymiany poglądów zarówno przez praktyków, jak i akademików. Wśród prelegentów znaleźli się przedstawiciele palestry, prokuratury, biura Rzecznika Praw Obywatelskich, jak również teoretycy prawa, co pozwoliło na spojrzenie na przyjęty temat konferencji z rozmaitych perspektyw. Uczestnicy konferencji uznali wystąpienia oraz dyskusję za inspirujące i pouczające, zwłaszcza mając na uwadze szczególną doniosłość obranego tematu. 